\title{
CYTOTOXICITY OF FILTRATES OF HAEMOLYTIC ESCHERICHIA COLI
}

\author{
U. C. Chaturvedi, Asha Mathur, A. M. Khan and \\ R. M. L. MEHrotra
}

The Upgraded Department of Pathology and Bacteriology, K.G. Medical College, Lucknow, India

\section{Plate XX}

WHILE we were investigating the characteristics of the diffusible haemolysin of Escherichia coli it occurred to us to study its effects on tissue cultures (Khan, Mehrotra and Kumar, 1968; Mehrotra et al., unpublished). The cytotoxic effects of the endotoxin of $E$. coli have been reported by Fumarola and Giordano (1966), but we have not come across any information on changes produced in tissue cultures by the diffusible haemolysin of E. coli.

\section{MATERIALS AND METHODS \\ Cells and haemolysin}

Cell strains. The various cell strains used to study the cytotoxic effects of haemolysin were $(a)$ chick fibroblasts prepared from 7-day-old chick embryos, $(b)$ monkey kidney epithelial cells obtained from young rhesus monkeys (Macaca mulatta) and (c) mouse fibroblasts from embryos on the 17 th day of gestation. Primary monolayer cultures were obtained after trypsinisation of the tissues. The growth medium consisted of Hanks' BSS with 3 per cent. calf serum and 0.5 per cent. lactalbumin hydrolysate. The tubes were incubated at $37^{\circ} \mathrm{C}$, and were used only when complete cell sheets had formed. Cell sheets were also grown on coverslips in Leighton tubes for studying cell morphology after staining.

Preparation of diffusible haemolysin of E. coli. Standard haemolytic strain 06 of E. coli obtained from Copenhagen, Denmark, was used for the preparation of diffusible haemolysin in alkaline extract broth according to the technique of Smith (1953).

Fractionation of haemolysin. The technique described by Mehrotra et al. for the fractionation of haemolysin by adsorbing it on calcium or aluminium gels was used and two fractions of haemolysin were obtained: fraction $\mathrm{A}$, the gel-adsorbed fraction of haemolysin, and fraction $B$, the supernatant from the adsorption procedure.

Haemolytic titre. This was determined in buffer salt solution $(p H 7 \cdot 0)$ with 2 per cent. washed sheep cells incubated at $37^{\circ} \mathrm{C}$ for $2 \mathrm{hr}$.

\section{Study of changes in the tissue cultures}

Morphological changes. Cell monolayers developed in the tubes within 24 to $48 \mathrm{hr}$ in chick embryo fibroblasts, in 5-6 days in monkey kidney cells and in 2-3 days in mouse embryo cells. Soon after the appearance of cell monolayers the growth medium was decanted and replaced by $0.5 \mathrm{ml}$ of Hanks' solution containing the desired dilution of the haemolysin. The tubes were incubated at $37^{\circ} \mathrm{C}$ and examined microscopically at intervals for evidence of cytotoxicity.

Received 4 Sept. 1968; accepted 15 Nov. 1968.

J. MED. MICROBIOL. - VOL. 2 (1969) 
Morphological changes were graded on the basis of percentage of destroyed and damaged cells. A damage of 75-100 per cent. of cells was classified as $++++; 50-75$ per cent. as $+++; 25-50$ per cent. as ++ ; and less than 25 per cent. as + . The coverslip preparations were stained with Jenner-Giemsa. The toxic dose was determined by inoculating ten-fold dilutions of the haemolysin into four culture tubes. The lowest concentration causing a ++ reaction after 2 hours' incubation was designated as the toxic dose. The 50 per cent. value of the toxic dose was determined by the method of Reed and Muench (1938).

Time required for cell damage. The haemolysin was diluted 1 in 10 in Hanks' solution and $0.5 \mathrm{ml}$ was added to tubes showing a full-grown sheet of chick embryo cells, after the growth medium had been decanted. In control tubes the culture fluid was replaced by Hanks' solution. The test and the control tubes were incubated at $37^{\circ} \mathrm{C}$. At 5 and $10 \mathrm{~min}$., and then every $10 \mathrm{~min}$. for $2 \mathrm{hr}$, one pair of test and one pair of control tubes were taken out, the fluid was decanted and the cell sheet was washed twice with Hanks' BSS and fresh Hanks' solution was added. The tubes were further incubated for $2 \mathrm{hr}$ at $37^{\circ} \mathrm{C}$ and then examined for cytotoxicity.

Viable count. The effect of haemolysin on the viable count of the chick embryo cells was studied by using washed trypsinised cells suspended in the growth medium to give a concentration of $0.8 \times 10^{6}$ cells per $\mathrm{ml}$. The haemolysin was added to give a final dilution of $10^{-0 \cdot 3}$ and $10^{-2 \cdot 3}$. The treated cells were incubated at $37^{\circ} \mathrm{C}$ and viable counts were done at hourly intervals with trypan blue as indicator. The results were expressed as percentage of viable cells.

Environmental temperature and cytotoxicity. Cytotoxic effects of haemolysin at different environment temperatures were studied by incubating the treated culture tubes at $4^{\circ} \mathrm{C}$ and $37^{\circ} \mathrm{C}$.

Neutralisation tests. Antisera against the soluble haemolysin were prepared in rabbits by Smith's technique and their neutralising activity was studied by three methods.

(a) A constant dilution of antiserum diluted 1 in 10 was mixed with an equal volume of varying dilutions of haemolysin and after incubation for $1 \mathrm{hr}$ at $37^{\circ} \mathrm{C}$ the mixture was added to the tissue-culture tubes. The tubes were examined for cytotoxicity after further incubation for $2 \mathrm{hr}$.

(b) A constant amount of anti-haemolysin diluted 1 in 10 was added to tissue-culture tubes which were then incubated at $37^{\circ} \mathrm{C}$ for $1 \mathrm{hr}$. Haemolysin was then added in doubling dilutions and the results were recorded after 2 hours' incubation.

(c) A fixed dilution ( 1 in 8 ) of haemolysin was inoculated into paired culture tubes. At $10,20,30,40,50$ and $60 \mathrm{~min}$. thereafter the anti-haemolysin, diluted 1 in 10 , was added to the tubes. After 2 hours' further incubation the tubes were examined for cytotoxicity.

In all these methods, appropriate controls with normal rabbit sera were run simultaneously.

\section{Heat-inactivated haemolysin}

The haemolysin was inactivated by heating at $56^{\circ} \mathrm{C}$ for $1 \mathrm{hr}$, and its haemolytic and cytotoxic activities were studied.

\section{Formalin-treated haemolysin}

Neutral 40 per cent. formaldehyde was added to the haemolysin to give a concentration of 0.4 per cent. formaldehyde. The mixture was incubated at $4^{\circ} \mathrm{C}$ for $1 \mathrm{hr}$, and tested for haemolytic and cytotoxic activity.

\section{Controls}

Throughout the study, suitable controls were employed, viz. (a) culture fluids from three non-haemolytic strains of $E$. coli, 01,02 and $05,(b)$ buffer solution, (c) synthetic media and $(d)$ media treated with the calcium phosphate gels used in the fractionation of haemolysin. Procedures similar to those used for the fractionation of haemolysin were also applied to the culture fluids from non-haemolytic $E$. coli with a view to find whether any of the latter fractions possessed cytotoxicity. Buffer salt solution was used at a $p \mathbf{H}$ of $7 \cdot 5$. Dilutions of haemolysin were prepared in Hanks' medium. 


\section{RESULTS}

\section{Toxicity of haemolysin to cell cultures}

The haemolysin had no cytotoxic effect on monkey kidney and mouse embryo cell cultures. The chick embryo cells were, however, found to be highly susceptible to haemolysin. Table I shows the grading of cell damage produced by the various dilutions of the haemolysin. Evidence of morphological damage was found down to a dilution of $10^{-7}$. Morphologically, the earliest change in the cells is rounding and swelling; the cytoplasm becomes granular and soon the cells lyse and drop from the glass surface. Stained

TABLE I

Cytotoxicity of haemolysin to chick embryo fibroblast cells

\begin{tabular}{|c|c|c|c|c|c|c|}
\hline \multirow{2}{*}{$\begin{array}{l}\text { Dilution of } \\
\text { haemolysin }\end{array}$} & \multicolumn{5}{|c|}{ Degree of cytotoxic change at $\mathrm{hr}$} & \multirow{2}{*}{$\begin{array}{l}\text { Regeneration } \\
\text { of cell sheet } \\
\text { after } 24 \mathrm{hr}\end{array}$} \\
\hline & $\frac{1}{2}$ & 1 & 2 & 3 & 4 & \\
\hline $\begin{array}{l}10^{0} \\
10^{-1} \\
10^{-2} \\
10^{-3} \\
10^{-4} \\
10^{-5} \\
10^{-6} \\
10^{-7} \\
10^{-8} \\
10^{-9}\end{array}$ & $\begin{array}{l} \pm \\
+ \\
\pm \\
- \\
- \\
= \\
= \\
=\end{array}$ & $\begin{array}{l}++ \\
++ \\
++ \\
++ \\
+ \\
\pm \\
= \\
=\end{array}$ & $\begin{array}{c}++++ \\
++++ \\
++++ \\
++++ \\
+++ \\
++ \\
++ \\
+ \\
+\end{array}$ & $\begin{array}{c}\text { Lysis } \\
++++ \\
++++ \\
++++ \\
+++++ \\
+++ \\
++ \\
+ \\
+\end{array}$ & $\begin{array}{c}\text { Lysis } \\
\text { Lysis } \\
\text { Lysis } \\
++++ \\
++++ \\
++++ \\
++ \\
+ \\
+ \\
-\end{array}$ & $\begin{array}{c}- \\
- \\
- \\
- \\
- \\
- \\
\text { Incomplete } \\
\text { Complete } \\
\text { Complete } \\
\text { Complete }\end{array}$ \\
\hline
\end{tabular}

Control fluids (filtrates from non-haemolytic E. coli strains 01, 02, 05; alkaline extract broth; and Hanks' fluid) produced no cytotoxic effects, and the cell sheet developed normally.

preparations of cells treated with higher concentrations of haemolysin show marked shrinkage of the cells with cytoplasmic opacity and nuclear pyknosis. With lower concentrations of haemolysin the cells are swollen, rounded or polygonal, with granular or vacuolated cytoplasm (figs. 1 and 2). The nuclei are also swollen and occasional nuclei show fragmentation. The 50 per cent. toxic dose of the haemolysin as calculated by the method of Reed and Muench was $10^{-6}$.

Culture fluids from three non-haemolytic strains of $E$. coli $(01,02$ and 05$)$ similarly treated did not produce any evidence of cell damage in chick fibroblast cells.

\section{Exposure period and cell damage}

A minimum of 20 minutes' contact of haemolysin with chick fibroblast culture cells is necessary for any demonstrable $(+)$ cytotoxic effect. The effect rises to + \pm at $50 \mathrm{~min}$; at $60 \mathrm{~min}$. the changes produced are significant and pronounced $(++)$; at $90 \mathrm{~min}$. the level is +++ , and at $110 \mathrm{~min} .++++$. Control tubes showed no cytotoxic effect. 


\section{Viable cell count}

When a fully developed sheet of chick fibroblasts was exposed to a 1 in 2 dilution of a particular batch of haemolysin, all the cells were killed in $1 \mathrm{hr}$. With a 1 in 200 dilution of the same batch of haemolysin, the percentage of viable cells fell to 79,58 and 25 at 1,2 and $3 \mathrm{hr}$. However, the cell sheet showed regeneration by $24 \mathrm{hr}$, by which time 40 per cent. of cells were viable.

TABLE II

Neutralisation of cytotoxicity of haemolytic filtrates with antisera

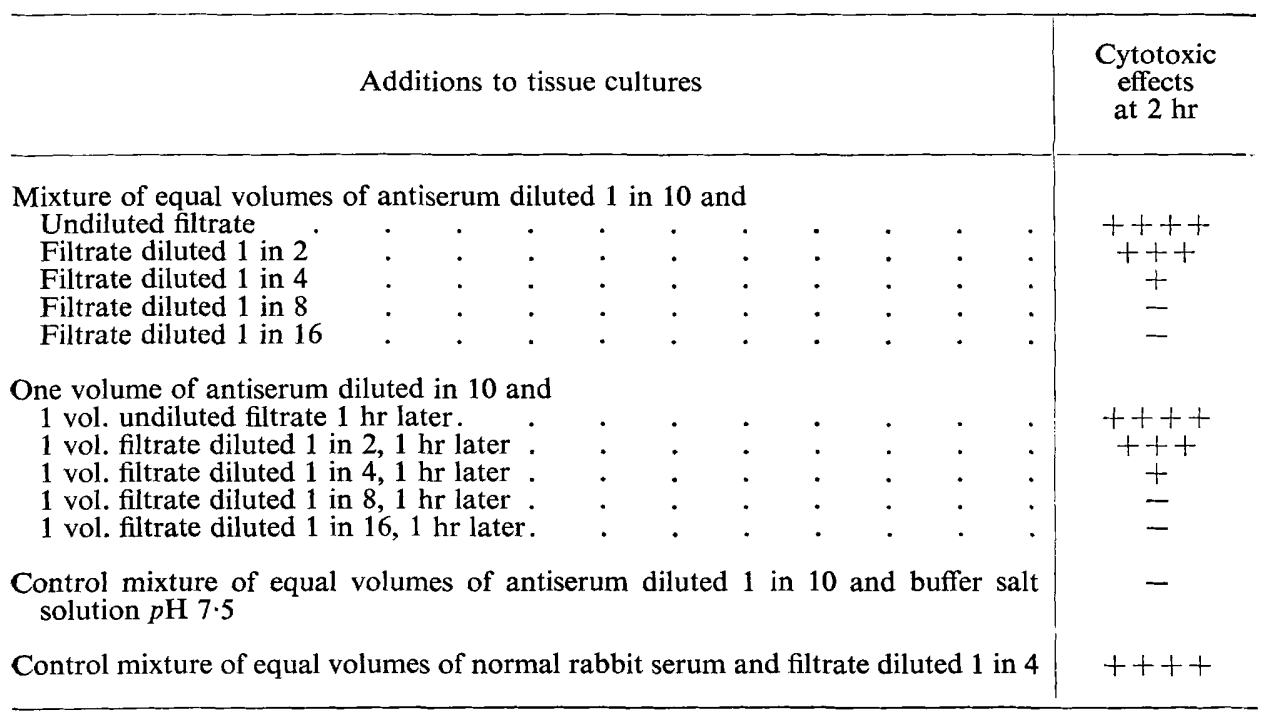

\section{Environmental temperature and cell damage}

There was almost no difference in the degree of cytotoxicity of the haemolysin at $4^{\circ} \mathrm{C}$ and $37^{\circ} \mathrm{C}$.

\section{Neutralisation of cytotoxicity}

A constant volume of anti-haemolysin diluted 1 in 10 completely neutralised the cytotoxic power of haemolysin diluted 1 in 8 or more (table II). The cytotoxicity of the haemolysin could also be completely abolished by pretreating the cell cultures with anti-haemolysin for a period of $60 \mathrm{~min}$. If the haemolysin was first added to the cell cultures and anti-haemolysin was added at a range of intervals, it was found that anti-haemolysin could neutralise the toxic effects if it was added up to $10 \mathrm{~min}$. after the addition of haemolysin.

\section{Cytotoxicity of haemolysin fractions}

Fraction A (gel-adsorbed) had no toxic effects on the cell cultures. Fraction B (the supernatant) was cytotoxic; the changes produced by it resembled those due to complete haemolysin, but they were rather less severe. Reconstituted 


\section{Cytotoxicity OF HAEMOLYTIC $E$. COLI Filtrates}

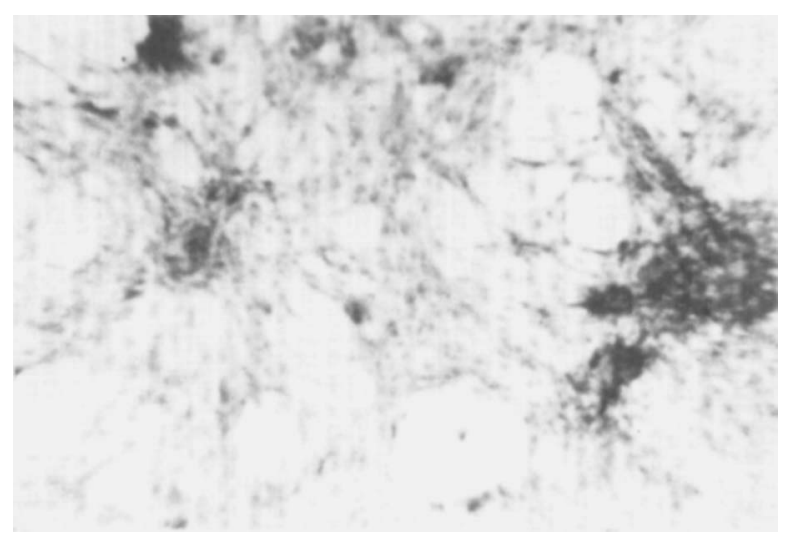

FIG. 1. Chick embryo cell culture. Normal cell sheet. Jenner-Giemsa. $\times 150$.

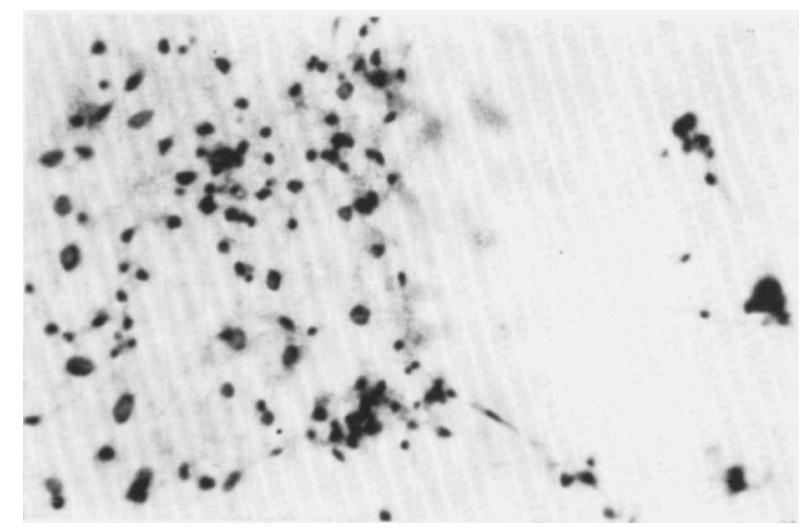

FIG. 2.--Chick embryo cell culture $2 \mathrm{hr}$ after treatment with diffusible haemolysin of Escherichia coli. Enlarged cells with granular cytoplasm and faintly stained swollen nuclei. A portion of the cell sheet shows lysis of cells. Jenner-Giemsa. $\times 150$. 
haemolysin obtained by mixing fractions $\mathrm{A}$ and $\mathrm{B}$ in the ratio of $1: 9$ showed the same degree of cytotoxicity as the original haemolysin.

\section{TABLE III}

Cytotoxicity and toxic dose of different fractions of haemolysin

\begin{tabular}{|c|c|c|c|c|c|}
\hline \multicolumn{4}{|c|}{ Preparation } & \multirow{2}{*}{ Cytotoxicity } & \multirow{2}{*}{ Toxic dose } \\
\hline No. & \multicolumn{3}{|c|}{ Nature } & & \\
\hline $\begin{array}{l}1 \\
2\end{array}$ & \multicolumn{3}{|c|}{$\begin{array}{l}\text { Fluid from haemolytic } E \text {. coli culture (diffusible toxin) } \\
\text { Fluid from non-haemolytic } E \text {. coli culture. }\end{array}$} & +++ & $\begin{array}{c}10^{-6} \\
-\end{array}$ \\
\hline 3 & Synthetic medium & . & . & - & - \\
\hline $\begin{array}{l}4 \\
5 \\
6 \\
7 \\
8 \\
9\end{array}$ & $\begin{array}{l}\text { Supernate from (1) after gel } t \\
\text { Precipitate from (1) after gel } \\
\text { Supernate from (2) after gel t } \\
\text { Precipitate from (2) after gel } \\
\text { Supernate from (3) after gel } t \\
\text { Precipitate from (3) after gel }\end{array}$ & $\begin{array}{l}\text { eatment } \\
\text { reatment } \\
\text { eatment } \\
\text { reatment } \\
\text { eatment } \\
\text { reatment }\end{array}$ & $\begin{array}{ll}: & : \\
: & : \\
: & :\end{array}$ & $\begin{array}{l}+++ \\
- \\
= \\
= \\
-\end{array}$ & $\begin{array}{l}10^{-4} \\
= \\
= \\
=\end{array}$ \\
\hline $\begin{array}{l}10 \\
11 \\
12\end{array}$ & $\begin{array}{l}\text { Mixture of } 4 \text { and } 5(9: 1) \\
\text { Mixture of } 6 \text { and } 7(9: 1) \text {. } \\
\text { Mixture of } 8 \text { and } 9(9: 1) \text {. }\end{array}$ & $\begin{array}{l}\cdot \\
\cdot\end{array}$ & $\dot{.}$ & $\begin{array}{c}+++ \\
- \\
-\end{array}$ & $\begin{array}{c}10^{-6} \\
- \\
-\end{array}$ \\
\hline 13 & Buffer salt solution $(p \mathrm{H} 7 \cdot 5)$ & . & . & - & - \\
\hline
\end{tabular}

TABLE IV

Haemolytic and cytotoxic activities of haemolysin after various treatments

\begin{tabular}{|c|c|c|}
\hline Material & $\begin{array}{c}\text { Haemolytic } \\
\text { titre }\end{array}$ & $\begin{array}{l}\text { Cytotoxic } \\
\text { titre }\end{array}$ \\
\hline $\begin{array}{l}\text { Heat-inactivated haemolytic filtrate. } \\
\text { Unheated haemolytic filtrate . }\end{array}$ & $\overline{128}$ & $\begin{array}{l}10^{-5} \\
10^{-6}\end{array}$ \\
\hline $\begin{array}{l}\text { Formalin-treated haemolytic filtrate } \\
\text { Formalin +-saline } \\
\text { Untreated haemolytic filtrate }\end{array}$ & $\frac{128}{128}$ & $\begin{array}{l}10^{-6} \\
10^{-1} \\
10^{-6}\end{array}$ \\
\hline
\end{tabular}

Differences in the degree of cytotoxicity of the haemolysin, reconstituted haemolysin and the supernatant fractions are also represented in their respective toxic doses. The toxic dose of the original and of the reconstituted haemolysin was $10^{-6}$; for fraction $B$ it was $10^{-4}$ (table III).

\section{Cytotoxic and haemolytic activities of the haemolysin}

Table IV shows that the haemolytic activity could be abolished by heating the haemolysin at $56^{\circ} \mathrm{C}$ for $1 \mathrm{hr}$, without destroying its cytotoxic activity. 
Addition of 0.4 per cent. formaldehyde did not affect either the haemolytic or the cytotoxic activities of the haemolysin.

Antisera prepared in rabbits against heated and unheated haemolysin to study the neutralising effects of these sera on the haemolytic and cytotoxic activities of the haemolysin were also investigated. Table $\mathrm{V}$ shows that the cytotoxic effect could be abolished by antisera prepared against either heated or unheated haemolysin. On the other hand, the haemolytic activity of the haemolysin could be neutralised only by antisera against unheated haemolysin.

TABLE V

Neutralisation of heat-inactivated and unheated haemolytic filtrate by homologous and heterologous antisera

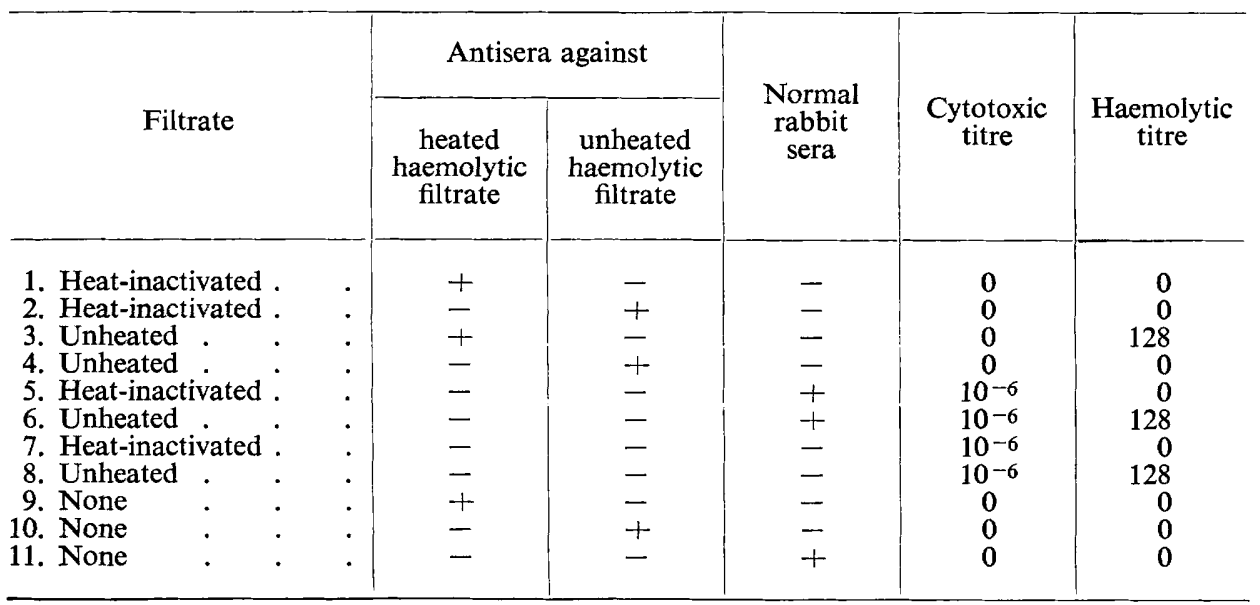

$+=$ Added; $-=$ not added; $0=$ no effect undiluted.

\section{Discussion}

The present study demonstrates that the diffusible haemolysin of Escherichia coli is cytotoxic to chick embryo fibroblast cultures, but has no effect on monkey kidney or mouse embryo cell cultures. No explanation for the selective toxicity of haemolysin is available, but the observations are in line with the reports of Gabliks and Solotorovsky (1962), who found differences in the toxic dose for different cell strains. They suggest that the susceptibility of the host tissues to toxin is reflected in the cell strains derived from it, and thus the characteristic is genetically determined.

The cell injury produced in chick embryo cultures by diffusible haemolysin was rapid and severe. Earliest morphological changes appeared within $20 \mathrm{~min}$. and by $4 \mathrm{hr}$ there was complete destruction of cell sheets. The minimum period for morphological injury of cell cultures has been found to vary from toxin to toxin and in different cell strains. Thus, chick embryo, guinea-pig and rabbit kidney cell cultures are destroyed within $18 \mathrm{hr}$ of exposure to diphtheria toxin, whereas human, monkey and dog kidney cultures do not disintegrate until 
$48 \mathrm{hr}$ after similar exposure (Gabliks and Solotorovsky). Similarly, Gladstone and Yoshida (1967) have demonstrated that the alpha-haemolysin of staphylococci produces damage within 2-3 min. in HLM, L and HEp cells, whereas HeLa cells require 10-15 minutes' exposure for the same degree of damage to be produced.

The cytotoxic effect of the haemolysin of $E$. coli is independent of environmental temperature, for no differences were found between cultures incubated at $4^{\circ} \mathrm{C}$ and at $37^{\circ} \mathrm{C}$. In this respect, the activity of haemolysin differs from that of other toxins (e.g., diphtheria), whose toxicity can be blocked by exposing the treated culture to a temperature of $10^{\circ} \mathrm{C}$, and thus preventing rapid adsorption of the toxin (Strauss and Hendee, 1959). The toxic effects were not due to the low $p \mathrm{H}$ of the haemolysin, for the chick embryo cell cultures were found to be unharmed in media with $p \mathrm{H}$ levels varying from 6 to 8 . That the toxic principle is elaborated only by haemolytic strains of $E$. coli is shown by the finding that culture filtrates of non-haemolytic $E$. coli are not cytotoxic to chick fibroblast cultures. The cytotoxic effect can be neutralised by specific antisera; anti-haemolysin is effective if added to tissue-culture tubes within 10 min. of addition of haemolysin. This catching-up interval is short in comparison with that of diphtheria toxin, which is neutralised up to $60 \mathrm{~min}$. after addition to cells (Gabliks and Falconer, 1966). The cytotoxicity is also abolished when haemolysin is mixed with anti-haemolysin before adding to the culture tubes or when the culture tubes are treated with anti-haemolysin before addition of haemolysin. Thus, the cytotoxicity of the haemolysin is specific. Similar neutralisation of other bacterial toxins in tissue cultures has been reported by Gabliks and Falconer and by Schaeffer, Gabliks and Calitis (1966) for diphtheria toxin and staphylococcal enterotoxin B.

The cytotoxic agent is, however, not identical with the diffusible haemolysin prepared according to the technique of Smith (1953). The haemolytic factor is thermolabile, whereas cytotoxic factor is thermostable. There are differences in the neutralisation effects of antibodies prepared against heated and unheated haemolysins. The antibodies against either of these prevent cytotoxicity, but haemolytic activity is checked only by antisera prepared against unheated haemolysin. Fraction A of haemolysin is non-haemolytic and non-cytotoxic, whereas fraction B is non-haemolytic but is cytotoxic.

\section{SUMMARY}

The diffusible haemolysin of Escherichia coli is highly cytotoxic to chick embryo cell cultures, but has no effect on monkey kidney and mouse embryo cell cultures. The cytotoxic effects are specific, as they can be neutralised by specific antisera. Culture fluids from non-haemolytic strains of $E$. coli are non-cytotoxic. The haemolytic activity is thermolabile, but cytotoxicity is thermostable. The antibodies prepared against heated or unheated haemolysins prevent cytotoxicity, but haemolytic activity is neutralised only by antisera prepared against unheated haemolysin. Fraction A of haemolysin is nonhaemolytic and non-cytotoxic, whereas fraction B is non-haemolytic but is cytotoxic. 
The haemolytic and cytotoxic factors of Escherichia coli appear, therefore, not to be identical.

We are grateful to Mr A. K. Kapoor and Mr M. P. Singh for providing fractions of haemolysin. We also thank Mr H. O. Tondon, Mr A. K. Roy and Mr Shaukat Ali for technical assistance. The financial assistance from the Research Grant of Lucknow University is gratefully acknowledged.

\section{REFERENCES}

Fumarola, D., ANd Giordano, D. 1966. Med. Pharmac. exp., Basel, 14, 65.

Gabliks, J., AND FALCONER, M. . $\quad$. 1966. J. Exp. Med., 123, 723.

GABliks, J., AND Solotorovsky, M. . 1962. J. Immun., 88, 505.

Gladstone, G. P., and Yoshida, A. 1967. Br. J. Exp. Path., 48, 11.

Khan, A. M., Mehrotra, R. M. L., AND 1968. Ind. J. Med. Res., 56, 1241.

KUMAR, R.

Reed, L. J., ANd Muench, H. . 1938. Amer. J. Hyg., 27, 493.

SChaEFFER, W. I., Gabliks, J., AND 1966. J. Bact., 91, 21. CALITIS, $R$.

SMith, J. . $\quad$. $\quad$. $\quad$. $\quad$. $\quad$. 1953. J. Path. Bact., 66, 503.

Strauss, N., and Hendee, Edelmira D. 1959. J. Exp. Med., 109, 145. 